\title{
Should mobile capital pay for public infrastructure investment?
}

\author{
Kersten Kellermann
}

\begin{abstract}
The paper contributes to the discussion of fiscal competition with infrastructure goods. We explicitly focus on the costs of providing public infrastructure capital that appear in the public budget as investment. Thus we analyse the problem in a dynamic framework. Public infrastructure is considered as a marginal product complement to private capital. A central result of the model is that the fact that public capital is a complement to private capital, so that an increase in the supply of public capital ceteris paribus improves the marginal productivity of private capital, cannot be used as an argument to support a source tax. The so-called indirect productivity effect on private capital induced by public inputs does not justify the taxation of mobile capital. Rather, the efficiency of a source tax on mobile capital income depends on the question of whether or not the public input generates a factor rent to private capital.
\end{abstract}

Keywords Fiscal competition - Public inputs - Infrastructure

JEL-Classifications $\quad \mathrm{H} 21 \cdot \mathrm{H} 73$

I thank two anonymous referees for helpful comments.

K. Kellermann $(\bowtie)$

Center of Public Finance, University of Fribourg,

Pérolles 90, Fribourg 1700, Switzerland

e-mail: kerstenkellermann@bluewin.ch

Present Address:

K. Kellermann

Städtle 4, Vaduz FL-9490, Liechtenstein 


\section{Introduction}

A standard argument in the theory of fiscal competition is that small open economies should not levy a source tax on international mobile capital, because capital will always be able to shift the tax burden to immobile factors (Wildasin 2000; Sinn 1997). However, it is still debatable whether a capital income tax is a proper instrument to finance productive public infrastructure. An essential contribution to the discussion of fiscal competition with infrastructure goods was made by Zodrow and Mieszkowski (1986), who oppose that a source-based capital tax is an efficient instrument to finance public inputs. ${ }^{1}$ A contrasting view is taken by Oates and Schwab (1991, 1988). They posit that a source tax on mobile capital can be interpreted as a benefit tax and thus justified as a price for public inputs. Any attempts to attract new business investment by lowering taxes below the cost of providing productive public goods will neither increase income nor create jobs in the community. Gerber and Hewitt (1987) attempt a synthesis of the two perspectives by categorizing the infrastructure goods according to their rivalry features. They distinguish between publicly provided private inputs and the "creation of atmosphere" type of public capital, as first described by Meade (1952), and conclude that a source tax is a proper instrument to finance publicly provided private inputs. Richter (1994) and Matsumoto (2000) discuss a fiscal competition model with so-called firm-augmenting public capital, where the costs of providing public inputs are assumed to rise with the number of firms in the jurisdiction. In this framework, a capital tax can be justified to avoid overly high profit taxes. A survey of different types of public inputs is given by Feehan (1989). Sinn $(2003,1997)$ considers infrastructure goods that lower the costs of using private capital. In his model, the government sets a source tax equal to the marginal congestion externality of private capital (Sinn 2003, p. 34).

Although most theoretical work in the area of infrastructure competition deals with the welfare implications of alternative ways of financing public capital, none of these studies examine government as an investing agent. In this paper we focus on the costs of providing and improving the public capital stock that appears in the public budget as investment. Thus the problem must be analyzed in a dynamic framework. $^{2}$ The policy question discussed in this paper is whether public infrastructure investment expenditures should be financed by mobile capital according to the benefit-taxation principle. We take the perspective of a small open economy that competes for mobile capital. Public infrastructure is considered as a marginal product complement to private capital. This means that public

\footnotetext{
${ }^{1}$ Zodrow and Mieszkowski (1986) argue that a source-based capital tax leads to an underprovision of public inputs even if the resulting tax income is used by the government to finance local public inputs. Thus, a jurisdictional government would prefer to tax its residents by a non-distorting lump sum tax. Noiset (1995) shows that in the framework of Zodrow and Mieszkowski, a tax on capital can under certain conditions also lead to an overprovison of public inputs. Matsumoto (1998) shows that Noiset's result of potential overprovision depends on the exogenity of the number of firms in the ZodrowMiezskowski model.

${ }^{2}$ Several previous studies have examined interesting aspects of intertemporal fiscal competition, e.g. Wildasin (2003b), Huizinga and Nielsen (1997).
} 
infrastructure influences the private factor productivity positively and can thus be used by the government in order to accommodate mobile capital (Pfähler et al. 1997). A central result of the model outlined in this paper is that the efficiency of a capital income tax depends not only on the rivalry features of public capital but also on the question of whether or not public capital generates a factor rent to private capital.

The paper is organized as follows. Section 2 reviews alternative specifications of public inputs which are based on the degree of homogeneity of the production function. Section 3 presents a dynamic model of a small open economy where private capital formation and saving decisions are influenced by a source-based tax, a flat rate wage tax and the supply of productive infrastructure. The markets for goods and inputs are perfectly competitive and both goods and private capital are perfectly mobile across borders. Section 4 is devoted to the question of how governments design an optimal investment and financing policy. According to the neoclassical approach, the public decision-maker seeks to promote social welfare, while acting as a price-taker in the capital market and not engaging in strategic interaction in response to the policies of neighbouring jurisdictions. ${ }^{3}$ In Sect. 5 the analysis explicitly indicates how the opportunity costs of public investments depend on the financing instruments used. Section 6 highlights in detail the incidence of a source tax in the steady state. It is then followed by some conclusions in Sect. 7

\section{Public investment and production technology}

Our first focus is the time-invariant production technologies used in the jurisdiction. There are different factors of production: labour $\mathrm{L}_{t}$, private capital $\mathrm{K}_{\mathrm{t}}$ and three kinds of public capital $\mathrm{G}_{\mathrm{i}, \mathrm{t}}$ (for $\mathrm{i}=\mathrm{P}, \mathrm{K}, \mathrm{L}$ ) which are used by private firms to produce one homogeneous good $\mathrm{Y}_{\mathrm{t}}$ at time $\mathrm{t}$. The price of $\mathrm{Y}_{\mathrm{t}}$ is normalized to unity. The labour supply grows at an exogenous rate $n$, thus $L_{t+1}=(1+n) L_{t}$. Capital is simply non-consumed output. The production function

$$
A\left(G_{P, t}\right) F\left(K_{t}, G_{K, t}, L_{t}, G_{L, t}\right)=Y_{t}
$$

exhibits positive diminishing marginal products with respect to each input, for all factors $L_{t}, K_{t}, G_{i, t}>0$ and the Inada conditions hold. All factors are complements in the sense that the second-order cross derivations of $A\left(G_{P, t}\right) F\left(K_{t}, G_{K, t}, L_{t}, G_{L, t}\right)$ are positive. The underlying production function for the private goods has increasing returns of scale in all inputs, but $F\left(K_{t}, G_{K, t}, L_{t}, G_{L, t}\right)$ is linear homogeneous in private capital, labour and all kinds of publicly provided private inputs. A further property of the production technology is that it faces diminishing returns to the accumulation of private and public capital together. Thus the production function specifies decreasing returns for fixed L. The public capital yields only production benefits, so

\footnotetext{
3 The question whether governments interact atomistically or like oligopolists is broadly discussed in the literature of fiscal competition (Wildasin 2003a). When the number of regions becomes small, strategic interaction between local governments plays an important role. Nevertheless, the aspect of strategic behaviour of the government is not considered in our model.
} 
that households are not immediate beneficiaries of public capital. ${ }^{4}$ In theoretical discussions, public inputs are mainly distinguished as follows (Feehan 1989; Arrow and Kurz 1970):

- The "creation of atmosphere type" of public capital $\left(\mathbf{G}_{\mathbf{P}, \mathbf{t}}\right)$ : This type of public input was first discussed by Meade (1952) and Kaizuka (1965) and applied to a fiscal competition framework by Zodrow and Mieszkowski (1986) and Matsumoto (1998). ${ }^{5}$ It exhibits no congestion externalities. The public capital stock $G_{P, t}$ determines the total factor productivity $A\left(G_{P, t}\right)$. The marginal effect of this specific kind of public infrastructure capital on total factor productivity is $\partial A\left(G_{P, t}\right) / \partial G_{P, t}$. Therefore total factor productivity is not considered to be exogenous but can be produced by the supply of $\mathrm{G}_{\mathrm{P}, \mathrm{t}}$. In the discussion of a new start for the so-called "Lisbon Strategy", the European Commission (2005) describes the public investments that a modern, knowledgeeconomy needs to adapt in the face of changing economic and social conditions. One of these public inputs is an effective regulation that has a significant positive impact on the framework conditions for economic growth and productivity. A second category of such public inputs is increased and improved public investment in R\&D. According to the European Commission (2005), public support for young and innovative companies in particular can improve total factor productivity. The quoted public inputs excellently describe what is meant by $\mathrm{G}_{\mathrm{P}, \mathrm{t}}$.

- The publicly provided private input $\left(\mathbf{G}_{\mathbf{K}, \mathbf{t}}\right.$ and $\left.\mathbf{G}_{\mathbf{L , t}, \mathbf{t}}\right)$ : The empirical literature on local public expenditure shows that many publicly provided inputs have roughly the same amount of rivalry as private goods (Gramlich 1994; Reiter and Weichenrieder 1997; Büttner et al. 2004). Government provides such private inputs because exclusion is either not possible or prohibitively expensive and a market solution thus unsatisfactory. Since the private production function exhibits constant returns in $\mathrm{K}_{\mathrm{t}}, \mathrm{L}_{\mathrm{t}}, \mathrm{G}_{\mathrm{L}, \mathrm{t}}$, and $\mathrm{G}_{\mathrm{K}, \mathrm{t}}$, the output $\mathrm{Y}_{\mathrm{t}}$ can be decomposed into the imputed shares of private capital, government capital and labour. According to Euler's theorem

$$
\mathrm{Y}_{\mathrm{t}}=\underbrace{\left[\frac{\partial \mathrm{Y}_{\mathrm{t}}}{\partial \mathrm{K}_{\mathrm{t}}} \mathrm{K}_{\mathrm{t}}+\frac{\partial \mathrm{Y}_{\mathrm{t}}}{\partial \mathrm{G}_{\mathrm{K}, \mathrm{t}}} \mathrm{G}_{\mathrm{K}, \mathrm{t}}\right]}_{\text {aggregate capital income }}+\underbrace{\left[\frac{\partial \mathrm{Y}_{\mathrm{t}}}{\partial \mathrm{L}_{\mathrm{t}}} \mathrm{L}_{\mathrm{t}}+\frac{\partial \mathrm{Y}_{\mathrm{t}}}{\partial \mathrm{G}_{\mathrm{L}, \mathrm{t}}} \mathrm{G}_{\mathrm{L}, \mathrm{t}}\right]}_{\text {aggregate wage income }}
$$

holds, so that national income is not exhausted if private inputs were paid their partial marginal product. We assume that private capital and labour have some way to appropriate the benefits of certain public inputs and convert them into private factor income. Thus, the income share of the publicly provided private capital is

\footnotetext{
${ }^{4}$ Wilson and Gordon (2003) discuss a model where households shift into or out of the jurisdiction in response to increases or decreases of local tax rate and public consumption services. They assume, however, that residents directly control tax rates whereas the government only controls expenditure.

5 This kind of public input is often referred to "factor-augmenting" because the benefits of the public input accrue not to firms as profits but to the factor owners (see McMillan 1979). Note, that the creation of atmosphere type of public capital induces only indirect productivity effects to capital and labour.
} 
distributed to private capital and labour, and both private factors are paid more than their partial marginal product (Gramlich 1994). ${ }^{6}$ We distinguish a publicly provided private input that is bound on labour $\left(\mathrm{G}_{\mathrm{L}, \mathrm{t}}\right)$ and another one that is bound on private capital $\left(\mathrm{G}_{\mathrm{K}, \mathrm{t}}\right)$. These publicly provided inputs can only be used by firms by employing private factors. An example of investments that increase $\mathrm{G}_{\mathrm{L}, \mathrm{t}}$ and improve labour income is public expenditure in education. According to the OECD (2005) resources for education in OECD countries depend heavily on the allocation of public budgets. Public funding today provides for most spending by educational institutions, with over $90 \%$ of primary and secondary expenditure coming from this source. Better-educated adults earn more on average. However, investment in education brings both individual and collective rewards. With respect to $G_{K, t}$ we think of public investment in a modern transportation and energy infrastructure. The European Commission (2005) argues that this kind of public investment in particular has a positive impact on private sector investment and enterprise decisions by improving the economic attractiveness of locations. The described example shows that public ownership of capital does not generate rents that directly enter the public budget, but generates factor rents. As long as public inputs are free of charge they can be interpreted as "unpaid factors".

\section{The private sector}

In the private sector, private capital has two costs to the firm: the rental price $r_{t}$ and a source-based tax on capital revenue, where $\theta_{\mathrm{K}, \mathrm{t}}$ denotes the capital tax rate. Firms invest capital up to the point where the marginal revenue of private investment equals the costs. Since firms are free to invest and produce domestically or abroad, net of tax return of capital is the same everywhere $r_{t}=r^{*}$. The supply of capital is completely price elastic. The marginal revenue of private capital

$$
\frac{\mathrm{r}^{*}}{1-\theta_{\mathrm{K}, \mathrm{t}}}=\frac{\partial \mathrm{Y}_{\mathrm{t}}}{\partial \mathrm{K}_{\mathrm{t}}}+\frac{\partial \mathrm{Y}_{\mathrm{t}}}{\partial \mathrm{G}_{\mathrm{K}, \mathrm{t}}} \frac{\mathrm{G}_{\mathrm{K}, \mathrm{t}}}{\mathrm{K}_{\mathrm{t}}}
$$

is the sum of the partial product of private capital $\partial \mathrm{Y}_{\mathrm{t}} / \partial \mathrm{K}_{\mathrm{t}}$ plus the output share of public capital appropriated by private capital $\left(\partial \mathrm{Y}_{\mathrm{t}} / \partial \mathrm{G}_{\mathrm{K}, \mathrm{t}}\right)\left(\mathrm{G}_{\mathrm{K}, \mathrm{t}} / \mathrm{K}_{\mathrm{t}}\right){ }^{7}$ Thus the aggregate domestic output

$$
\mathrm{Y}_{\mathrm{t}}=\mathrm{r}^{*} \mathrm{~K}_{\mathrm{t}}+\mathrm{W}_{\mathrm{t}}+\left(\frac{\partial \mathrm{Y}_{\mathrm{t}}}{\partial \mathrm{K}_{\mathrm{t}}} \mathrm{K}_{\mathrm{t}}+\frac{\partial \mathrm{Y}_{\mathrm{t}}}{\partial \mathrm{G}_{\mathrm{K}, \mathrm{t}}} \mathrm{G}_{\mathrm{K}, \mathrm{t}}\right) \theta_{\mathrm{K}, \mathrm{t}}
$$

\footnotetext{
${ }^{6}$ In the literature we also find "firm-augmenting" public inputs that are congestible among firms and "semi-public input" congestible within industries. Since we argue in a one-sector model, semi-public inputs are not considered. Firm-augmenting public inputs are unpaid factors that generate a rent, which can be absorbed by firms as a profit. In a fiscal competition framework, firm-augmenting public inputs that generate profits are discussed by Richter (1994) and Matsumoto (2000).

7 This assumption is also found by Oates and Schwab (1991, p. 130) and Gerber and Hewitt (1987, p. 456).
} 
can be decomposed in an income share that goes to the mobile factor $\mathrm{r}^{*} \mathrm{~K}_{\mathrm{t}}$, the gross wage income $\mathrm{W}_{\mathrm{t}}$ that goes to the immobile private households and the source tax revenue received by the government.

Since we assumed that all factors are marginal product complements, the secondorder cross derivations of $\mathrm{Y}_{\mathrm{t}}$ are positive. Therefore all three kinds of public capital have a so-called indirect productivity effect on private capital in the sense that an increase in the supply of $G_{i, t}$ raises the partial productivity of private capital. However, only $G_{K, t}$ that is distributed among firms in proportion to each firm's capital stock generates a rent to private capital. Equation 2 shows that ceteris paribus, an inflow of a marginal unit of private capital lowers the rent appropriated by each unit of private capital invested in the jurisdiction and thus creates a negative externality to private capital. This reminds us of congestion externalities as modelled by Sinn $(2003,1997)$. However in our model the source tax is not justified by externalities. What should in fact be the bad side of lowering a rent that goes to the mobile factor? As will be shown, the potential problem of a marginal capital inflow is the induced marginal effect to capital income that may exceed its partial output effect if the source tax is chosen on an inefficient level.

The household sector is designed according to the overlapping-generations model. An individual born at time t supplies a fixed amount of labour and pays a proportional tax rate $\theta_{\mathrm{L}, \mathrm{t}}$ on per capita wage income $\mathrm{w}_{\mathrm{t}}=\mathrm{W}_{\mathrm{t}} / \mathrm{L}_{\mathrm{t}}$. Since labour is supplied inelastically, the wage tax can be considered as equivalent to a lump sum tax. From the perspective of the private agents, the fiscal parameters $\mathrm{G}_{\mathrm{i}, \mathrm{t}}, \theta_{\mathrm{K}, \mathrm{t}}$, and $\theta_{\mathrm{L}, \mathrm{t}}$ are exogenous. Each young person consumes $\overline{\mathrm{c}}_{\mathrm{t}}^{\mathrm{y}}$ of the net income and saves the remainder $\mathrm{s}_{\mathrm{t}}=\left(1-\theta_{\mathrm{L}, \mathrm{t}}\right) \mathrm{w}_{\mathrm{t}}-\overline{\mathrm{c}}_{\mathrm{t}}^{\mathrm{y}}$. In the second period of his life the individual consumes $\bar{c}_{t+1}^{o}$ that equals all his wealth, both interest and principal $\overline{\mathrm{c}}_{\mathrm{t}+1}^{\mathrm{o}}=\mathrm{s}_{\mathrm{t}}\left(1+\mathrm{r}^{*}\right)$. Like firms, private households have access to the world capital market so $r^{*}$ is the time-invariant return on private saving. Domestic and foreign claims on capital are assumed to be perfect substitutes as stores of value. No residence-based tax on capital income is levied. The decision problem for young people is to maximize the lifetime log utility function $\mathrm{u}\left(\overline{\mathrm{c}}_{\mathrm{t}}^{\mathrm{y}}, \overline{\mathrm{c}}_{\mathrm{t}+1}^{\mathrm{o}}\right)=\ln \overline{\mathrm{c}}_{\mathrm{t}}^{\mathrm{y}}+\vartheta \ln \overline{\mathrm{c}}_{\mathrm{t}+1}^{\mathrm{o}}$, with $0<\vartheta<1$, subject to the budget constraint $\overline{\mathrm{c}}_{\mathrm{t}}^{\mathrm{y}}=\left(1-\theta_{\mathrm{L}, \mathrm{t}}\right) \mathrm{w}_{\mathrm{t}}-\overline{\mathrm{c}}_{\mathrm{t}+1}^{\mathrm{o}} /\left(1+\mathrm{r}^{*}\right)$. The parameter $\vartheta$ denotes the subjective discount factor. The assumption of a log utility function leads to a constant ratio of individual optimal consumption in the first and second period of lifetime, which simplifies the following analyses. The optimal consumption of somebody born in $t$ when in old age is $c_{t+1}^{o}=\vartheta\left(1+r^{*}\right) c_{t}^{y}$. The lifetime budget constraint of the private household is thus given by

$$
0=\left(1-\theta_{\mathrm{L}, \mathrm{t}}\right) \mathrm{w}_{\mathrm{t}}-(1+\vartheta) \mathrm{c}_{\mathrm{t}}^{\mathrm{y}}
$$

The indirect utility function, that expresses the maximum utility achievable by the private household at a given interest rate $r^{*}$ and wage income is given by

$$
\mathrm{v}\left(\mathrm{w}_{\mathrm{t}}, \theta_{\mathrm{L}, \mathrm{t}}, \mathrm{r}^{*}, \vartheta\right)=\left\{\ln \frac{1}{(1+\vartheta)}+\vartheta \ln \frac{\vartheta\left(1+\mathrm{r}^{*}\right)}{(1+\vartheta)}\right\}+(1+\vartheta) \ln \left(\mathrm{W}_{\mathrm{t}}-\phi_{\mathrm{L}, \mathrm{t}} / \mathrm{L}_{\mathrm{t}}\right)
$$




\section{The welfare maximizing tax and investment strategy of an autonomous jurisdiction}

The government's total tax revenue is the sum of the capital tax revenue $\phi_{\mathrm{K}, \mathrm{t}}=$ $\left(\mathrm{Y}_{\mathrm{t}}-\mathrm{W}_{\mathrm{t}}\right) \theta_{\mathrm{K}, \mathrm{t}}$ and the wage tax revenue $\phi_{\mathrm{L}, \mathrm{t}}=\mathrm{W}_{\mathrm{t}} \theta_{\mathrm{L}, \mathrm{t}}$. Both tax rates $\theta_{\mathrm{L}, \mathrm{t}}$ and $\theta_{\mathrm{K}, \mathrm{t}}$ are allowed to be time-variant. Public investment is $\sum_{\mathrm{i}=\mathrm{P}, \mathrm{K}, \mathrm{L}} \mathrm{G}_{\mathrm{i}, \mathrm{t}+1}-\left(1-\chi_{\mathrm{i}}\right) \mathrm{G}_{\mathrm{i}, \mathrm{t}}$ and $\chi_{\mathrm{i}}$ denotes the appropriate depreciation rate. Public consumption is neglected in the model. The budget constraint of the public sector is thus given by

$$
\sum_{\mathrm{i}=\mathrm{P}, \mathrm{K}, \mathrm{L}}\left[\mathrm{G}_{\mathrm{i}, \mathrm{t}+1}-\left(1-\chi_{\mathrm{i}}\right) \mathrm{G}_{\mathrm{i}, \mathrm{t}}\right]-\phi_{\mathrm{L}, \mathrm{t}}-\phi_{\mathrm{K}, \mathrm{t}}=0 \text {. }
$$

We assume that the government has the objective to maximize the utility $\mathrm{v}\left(\mathrm{w}_{\mathrm{t}}, \phi_{\mathrm{L}, \mathrm{t}}, \mathrm{r}^{*}, \vartheta\right)$ of its residents and discounts the utility of future generations at rate $\lambda>0$. The government maximizes a social welfare function of the form $\Psi=\sum_{t=1}^{T=\infty}(1+\lambda)^{1-\mathrm{t}} \mathrm{v}\left(\mathrm{w}_{\mathrm{t}}, \phi_{\mathrm{L}, \mathrm{t}}, \mathrm{r}^{*}, \vartheta\right)$ over an infinite optimization horizon ${ }^{8}$ subject to the private constraint (2) and the public budget constraint (5). Furthermore, additional constraints hold that $\mathrm{G}_{\mathrm{i}, 1}$ are given. Accordingly, the Lagrangian expression is

$$
\begin{gathered}
\mathrm{Z}\left(\phi_{\mathrm{K}, \mathrm{t}}, \phi_{\mathrm{L}, \mathrm{t}}, \mathrm{G}_{\mathrm{i}, \mathrm{t}+1}, \mathrm{~K}_{\mathrm{t}+1}\right)=\Psi+\sum_{t=1}^{T} \mu_{\mathrm{t}}\left[\phi_{\mathrm{L}, \mathrm{t}}+\phi_{\mathrm{K}, \mathrm{t}}-\sum_{\mathrm{i}=\mathrm{P}, \mathrm{K}, \mathrm{L}} \mathrm{G}_{\mathrm{i}, \mathrm{t}+1}+\left(1-\chi_{\mathrm{i}}\right) \mathrm{G}_{\mathrm{i}, \mathrm{t}}\right] \\
+\sum_{t=1}^{T} \rho_{\mathrm{t}}\left[\mathrm{Y}_{\mathrm{t}}\left(\mathrm{G}_{\mathrm{i}, \mathrm{t}}, \mathrm{K}_{\mathrm{t}}\right)-\mathrm{W}_{\mathrm{t}}\left(\mathrm{G}_{\mathrm{i}, \mathrm{t}}, \mathrm{K}_{\mathrm{t}}\right)-\phi_{\mathrm{K}, \mathrm{t}}-\mathrm{r}^{*} \mathrm{~K}_{\mathrm{t}}\right]
\end{gathered}
$$

where the Lagrange multipliers $\mu_{\mathrm{t}}$ and $\rho_{\mathrm{t}}$ are functions of the time $\mathrm{t}$. The control variables of the government are the capital tax revenue $\phi_{\mathrm{K}, \mathrm{t}}=\left(\mathrm{Y}_{\mathrm{t}}-\mathrm{W}_{\mathrm{t}}\right) \theta_{\mathrm{K}, \mathrm{t}}$, the wage tax revenue $\phi_{\mathrm{L}, \mathrm{t}}=\mathrm{W}_{\mathrm{t}} \theta_{\mathrm{L}, \mathrm{t}}$ and the three kinds of public capital $\mathrm{G}_{\mathrm{i}, \mathrm{t}}$ (for $\mathrm{i}=\mathrm{P}$, $\mathrm{K}, \mathrm{L}$ ). From the first-order conditions of the optimization problem - presented in the Appendix - we deduce the shadow price in utility terms of tax revenue $\mu_{\mathrm{t}}$ that depends on the underlying tax instrument:

$$
\begin{gathered}
\mu_{\mathrm{t}} \leq(1+\lambda)^{1-\mathrm{t}}(1+\vartheta)\left\{\frac{1}{\left(\mathrm{~W}_{\mathrm{t}}-\phi_{\mathrm{L}, \mathrm{t}}\right)}\right\} \quad \phi_{\mathrm{L}, \mathrm{t}} \geq 0 ; \quad \phi_{\mathrm{L}, \mathrm{t}} \frac{\partial Z}{\partial \phi_{\mathrm{L}, \mathrm{t}}}=0 \\
\mu_{\mathrm{t}} \leq(1+\lambda)^{1-\mathrm{t}}(1+\vartheta) \frac{1}{\left(\mathrm{~W}_{\mathrm{t}}-\phi_{\mathrm{L}, \mathrm{t}}\right)} \frac{\left\{\frac{\partial \mathrm{W}_{\mathrm{t}}}{\partial \mathrm{K}_{\mathrm{t}}}\right\}}{\left[\mathrm{r}^{*}-\frac{\partial\left(\mathrm{Y}_{\mathrm{t}}-\mathrm{W}_{\mathrm{t}}\right)}{\partial \mathrm{K}_{\mathrm{t}}}\right]} \quad \phi_{\mathrm{K}, \mathrm{t}} \geq 0 ; \phi_{\mathrm{K}, \mathrm{t}} \frac{\partial Z}{\partial \phi_{\mathrm{K}, \mathrm{t}}}=0
\end{gathered}
$$

\footnotetext{
${ }^{8}$ If the government has the same time horizon as the private household, then $T=1$. In this case the government does not engage in public investment at all. The reason is that public investment undertaken in period $\mathrm{t}$ affects only wage income earned in later periods, whereas the tax burden of financing this public investment occurs in period $t$.
} 
From (1) and (2) we know $\mathrm{r}_{\mathrm{t}}^{*}=\left(\mathrm{Y}_{\mathrm{t}}-\mathrm{W}_{\mathrm{t}}-\phi_{\mathrm{K}, \mathrm{t}}\right) / \mathrm{K}_{\mathrm{t}}$. The public decision-maker uses the tax instrument that causes fewer utility losses for the private sector. Thus a source-based tax on capital revenue $\phi_{\mathrm{K}, \mathrm{t}} \geq 0$ is chosen only if the first term of condition (8) is binding. In this case the shadow price of a capital tax is smaller than or equal to the shadow price of a wage tax. To meet this requirement

$$
\phi_{\mathrm{K}, \mathrm{t}}=\theta_{\mathrm{K}, \mathrm{t}}\left(\mathrm{Y}_{\mathrm{t}}-\mathrm{W}_{\mathrm{t}}\right) \leq\left[\left(\mathrm{Y}_{\mathrm{t}}-\mathrm{W}_{\mathrm{t}}\right)-\frac{\partial \mathrm{Y}_{\mathrm{t}}}{\partial \mathrm{K}_{\mathrm{t}}} \mathrm{K}_{\mathrm{t}}\right]
$$

must hold. Using Eq. 2 it can be shown that the amount of taxes contributed by private capital never exceeds the share of public capital income that is appropriated by private capital $\left(\partial Y_{t} / \partial G_{K, t}\right) G_{K, t}$. Given an interior solution the optimal source tax rate is

$$
\theta_{\mathrm{K}, \mathrm{t}}^{*}=\frac{\frac{\partial \mathrm{Y}_{\mathrm{t}}}{\partial \mathrm{G}_{\mathrm{K}, \mathrm{t}}} \mathrm{G}_{\mathrm{K}, \mathrm{t}}}{\left(\mathrm{Y}_{\mathrm{t}}-\mathrm{W}_{\mathrm{t}}\right)} .
$$

Thus the optimal public policy is to tax away the rents appropriated by the private capital so that the corresponding tax revenue equals exactly the share of public capital income $\left(\partial \mathrm{Y}_{\mathrm{t}} / \partial \mathrm{G}_{\mathrm{K}, \mathrm{t}}\right) \mathrm{G}_{\mathrm{K}, \mathrm{t}}$. This result is suggestive of Sandmo (1972), who defines an optimal tax to finance a firm-augmenting public input as a direct charge on firms. In Sandmo (1972), the firm-augmenting public input can be interpreted as an unpaid factor that generates an excess profit to private firms. Since $G_{K, t}$ represents an unpaid factor that generates a factor rent to private capital, $\phi_{\mathrm{K}, \mathrm{t}} *$ is a direct charge on private capital for the supply of $G_{K, t}$. However, as shown in Kellermann (2006) the revenue of this benefit tax is not cost equivalent in the sense that the tax revenue $\phi_{\mathrm{K}, \mathrm{t}}{ }^{*}=\left(\mathrm{Y}_{\mathrm{t}}-\mathrm{W}_{\mathrm{t}}\right) \theta_{\mathrm{K}, \mathrm{t}} *$ covers exactly the public expense caused by the optimal provision of $\mathrm{G}_{\mathrm{K}, \mathrm{t}}$.

That rents earned by mobile factors provides an efficient and thus highly desirable means of raising tax revenue is certainly not a surprisingly result. Zodrow (2006) quotes several arguments supporting source-based capital income taxes on account of rents. What in a way may surprise, is that according to Eq. 9 neither the supply of public capital from the creation of atmosphere type $G_{P, t}$ nor the supply of $G_{L, t}$ justifies a source tax on capital. The fact that $G_{P, t}$ and $G_{L, t}$ are complements to private capital, so that an increase in the supply of both kinds of public capital ceteris paribus improves the marginal productivity of private capital, cannot be used as an argument to support a source tax. If the output elasticity of $\mathrm{G}_{\mathrm{K}, \mathrm{t}}$ is assumed to be zero, so that public capital generates no rents to private capital, then $\theta_{\mathrm{K}, \mathrm{t}}{ }^{*}=0$ despite the beneficial impact of $\mathrm{G}_{\mathrm{P}, \mathrm{t}}$ and $\mathrm{G}_{\mathrm{L}, \mathrm{t}}$ that goes to private capital.

In this respect, the optimal tax rule given by Eq. 9 deviates from the result derived by Feehan and Matsumoto (2000). By examining the case of a creation of atmosphere type of public capital, ${ }^{9}$ they argue that each of the private factors should be taxed proportional to the change in this factor's marginal productivity due to a

\footnotetext{
9 Feehan and Matsumoto (2000) use the expression factor-augmenting public input.
} 
marginal change in the public input. However, Feehan and Matsumoto (2000) do not consider the case of a small open economy that competes for mobile capital but argue in a static world where domestic factors are fixed in supply. Thus the problem of capital flight is neglected. Compared with this, in our model capital flight is a major concern of the welfare maximizing government. If the output elasticity of $\mathrm{G}_{\mathrm{K}, \mathrm{t}}$ is assumed to be zero, a source tax rate $\theta_{\mathrm{K}, \mathrm{t}}>0$ leads to inefficient low private investment. Condition (2) shows that in this case the partial marginal output of private capital exceeds the world interest rate $\partial Y_{t} / \partial K_{t}>r^{*}$. The income share of the immobile factors, i.e. labour income and tax revenue, can thus be improved by further capital inflows. The world interest rate $r^{*}$ can be interpreted as the opportunity costs of private capital to the small open economy. In other words, a reduction of the source tax raises wage income by more than the induced loss of tax revenue, so that private households prefer a wage tax to a source tax. The only exception occurs if the partial marginal productivity of $\partial \mathrm{Y}_{\mathrm{t}} / \partial \mathrm{K}_{\mathrm{t}}<\mathrm{r}^{*}$. In this case the output elasticity of $\mathrm{G}_{\mathrm{K}, \mathrm{t}}$ is positive and the mobile private capital appropriates a factor rent, that according to (9) justifies a source tax.

Note that for $\theta_{\mathrm{K}, \mathrm{t}}=\theta_{\mathrm{K}, \mathrm{t}} *$ the private marginal rate of time preference $\left[\left(\partial u / \partial \mathrm{c}_{1}^{\mathrm{y}}\right) /\right.$ $\left.\left(\partial u / \partial c_{1+1}^{0}\right)-1\right]$ as well as the partial productivity of private capital equalizes the marked interest rate $\mathrm{r}^{*}$. On that score in the private sector, the source tax rate $\theta_{\mathrm{K}, \mathrm{t}}{ }^{*}$ makes a first best solution possible. According to the so-called "second-best shadow pricing approaches", discussed in the theory of optimal taxation, we would expect that in this case the government should also use $\mathrm{r}^{*}$ as a social discount rate (Sandmo and Drèze 1971; Marchand and Pestieau 1984). However, from the optimization problem (6) and condition (3) we receive the optimal investment path of the jurisdictional government as

$$
\frac{\partial Y_{t+1}}{\partial G_{i, t+1}}=(1+\lambda)(1+n) \frac{c_{t+1}^{y}}{c_{t}^{y}}-\left(1-\chi_{i}\right) .
$$

Condition (10) can be interpreted as a modified golden rule of government investment (Barro and Sala-i-Martin 1995). It states that decreasing lifetime consumption for the individuals working in period t leads to a decrease of their utility $\mathrm{L}_{\mathrm{t}} \frac{\partial u}{\partial \mathrm{c}_{\mathrm{t}}^{\mathrm{y}}}=\mathrm{L}_{\mathrm{t}} \frac{(1+\vartheta)}{\mathrm{c}_{\mathrm{t}}^{\mathrm{y}}}$ but makes an increase in the utility of the individuals working in period $t+1$ possible through public capital accumulation. According to the optimality condition, this utility increase discounted to $t$ using the social discount rate $\lambda$ $>0$ must equal the initial utility decrease. Condition (10) shows that the rate of return on government capital does not unconditionally equal the marginal product of private capital, which according to (2) and (9) equals $r^{*}$. Rather, it would appear that $r^{*}$ (and with that the private rate of time preference) exceeds the marginal social rate of time preference. ${ }^{10}$

\footnotetext{
${ }^{10}$ Marglin (1963) discusses some reasons why there should be a difference between the way we view saving versus consumption decisions collectively and the way we view these decisions individually. Nevertheless, the assumption that the private rate of time preference differs from the social one is not decisive for our results. Marglin (1963) discusses some reasons why there should be a difference between the way we view saving versus consumption decisions collectively and the way we view these decisions individually. Nevertheless, the assumption that the private rate of time preference differs from the social one is not decisive for our results.
} 


\section{Restriction to a wage tax or a source tax}

What happens if the government is restricted to one or the other tax instrument for whatever reason? First we consider the case where only a wage tax is imposed, so that the optimal investment path of the jurisdictional government is given by:

$$
\begin{aligned}
& \frac{\partial Y_{t+1}}{\partial G_{i, t+1}}=\left[(1+\lambda)(1+n) \frac{c_{t+1}^{y}}{c_{t}^{y}}-\left(1-\chi_{i}\right)\right] \\
& +\left[\frac{\partial Y_{t+1}}{\partial G_{K, t+1}} G_{K, t+1}\right] \frac{\partial\left[\frac{\left.\partial Y_{t+1} K_{t+1}+\frac{\partial Y_{t+1}}{\partial G_{t+1}} G_{K, t+1}\right]}{\frac{\partial W_{t+1}}{\partial K_{t+1}} K_{t+1}+\frac{\partial Y_{t+1}}{\partial G_{K, t+1}} G_{K, t+1}}\right.}{\partial G_{i, t+1}}
\end{aligned}
$$

This optimality condition equals (10) only if the output share of public inputs appropriated by mobile capital $\left[\partial \mathrm{Y}_{\mathrm{t}+1} / \partial \mathrm{G}_{\mathrm{K}, \mathrm{t}+1}\right] \mathrm{G}_{\mathrm{K}, \mathrm{t}+1}$ is zero, so that the second part of the RHS of Eq. 11 disappears. In this case $\theta_{\mathrm{K}, \mathrm{t}}{ }^{*}=0$ holds and condition (9) is not violated by the restriction, but it is efficient to finance all public investments by a wage tax.

Equation (11) shows that the opportunity costs of all three kinds of public inputs include the excess burden incurred by a non-optimal tax policy. Although the wage tax itself can be interpreted as a non-disturbing lump sum tax, it is not the appropriate tax instrument to confiscate the private capital's factor rent. Thus the restriction to a wage tax leads to the problem of an inefficiently high inflow of private capital. Equation (2) shows that for $\theta_{\mathrm{K}, \mathrm{t}}=0$ the marginal output effect of private capital, i.e. its partial productivity is lower than the marginal revenue of private capital $\mathrm{r}^{*}$. Excluding the source tax, it becomes impossible to reach the optimum described by Eq. 9. Furthermore, investment in $\mathrm{G}_{\mathrm{K}, \mathrm{t}}$ now has to be financed by a wage tax, which again lowers the available income of the private households. Assuming constant output elasticities $\alpha, \beta$ and $\varepsilon_{\mathrm{i}}(\mathrm{i}=\mathrm{L}, \mathrm{K}, \mathrm{P})$ with respect to labour, private capital and all three kinds of public capital, (11) reduces to

$$
\frac{\partial \mathrm{Y}_{\mathrm{t}+1}}{\partial \mathrm{G}_{\mathrm{i}, \mathrm{t}+1}}=\left[(1+\lambda)(1+\mathrm{n}) \frac{\mathrm{c}_{\mathrm{t}+1}^{\mathrm{y}}}{\mathrm{c}_{\mathrm{t}}^{\mathrm{y}}}-\left(1-\chi_{\mathrm{i}}\right)\right] \frac{\left(\alpha+\varepsilon_{\mathrm{L}}\right) \beta+\varepsilon_{\mathrm{K}}}{\left(\alpha+\varepsilon_{\mathrm{L}}\right)\left(\beta+\varepsilon_{\mathrm{K}}\right)}
$$

Equation (11') shows that the opportunity costs rise unequivocally with respect to all public factors and are the same for $\mathrm{G}_{\mathrm{P}, \mathrm{t}+1}, \mathrm{G}_{\mathrm{L}, \mathrm{t}+1}$ and $\mathrm{G}_{\mathrm{K}, \mathrm{t}+1}$. Only for $\varepsilon_{\mathrm{K}}=0 \mathrm{Eq}$. (11') equals Eq. (10).

If the government is restricted to a source tax, the opportunity costs of public investment become 


$$
\begin{aligned}
& \frac{\partial \mathbf{Y}_{t+1}}{\partial \mathbf{G}_{\mathrm{i}, t+1}}=\left((1+\lambda)(1+\mathrm{n}) \frac{\mathrm{c}_{\mathrm{t}+1}^{\mathrm{y}}}{\mathrm{c}_{\mathrm{t}}^{\mathrm{y}}} \frac{\left[\frac{\partial \mathbf{W}_{\mathrm{t}}}{\partial \mathbf{K}_{\mathrm{t}}}\right]\left[\mathrm{r}^{*}-\frac{\partial\left(\mathbf{Y}_{\mathrm{t}+1}-\mathbf{W}_{\mathrm{t}+1}\right.}{\partial \mathbf{K}_{\mathrm{t}+1}}\right]}{\left[\frac{\partial \mathbf{W}_{\mathrm{t}+1}}{\partial \mathbf{K}_{\mathrm{t}+1}}\right]\left[\mathrm{r}^{*}-\frac{\partial \mathbf{Y}_{\mathrm{t}}-\mathbf{W}_{\mathrm{t}}}{\partial \mathbf{K}_{\mathrm{t}}}\right]}-\left(1-\chi_{\mathrm{i}}\right)\right) \\
& -\left\{\left[\frac{\partial Y_{t+1}}{\partial G_{K, t+1}} G_{K, t+1}\right]-\sum_{i=P, K, L}\left[G_{i, t+2}-\left(1-\chi_{i}\right) G_{i, t+1}\right]\right\} \frac{\left[\frac{\partial W_{t+1}}{\partial} G_{i, t+1}\right]}{\left[\frac{\partial W_{t+1} K_{t+1}}{\partial K_{t+1}}\right]}
\end{aligned}
$$

Under the arbitrary assumption that total public net investment $\sum_{\mathrm{i}=\mathrm{P}, \mathrm{K}, \mathrm{L}}\left[\mathrm{G}_{\mathrm{i}, \mathrm{t}+1}-\left(1-\chi_{\mathrm{i}}\right) \mathrm{G}_{\mathrm{i}, \mathrm{t}}\right]$ equals the factor rent $\frac{\partial \mathrm{Y}_{\mathrm{t}+1}}{\partial \mathrm{G}_{\mathrm{K}, \mathrm{t}+1}} \mathrm{G}_{\mathrm{K}, \mathrm{t}+1}$, the restriction on a source tax is not binding. In this case the second term of the RHS of Eq. (12) vanishes and since $r^{*}=\partial Y_{t} / \partial K_{t}$ the whole expression (12) reduces to (10). In all other cases, the restriction on a source tax is binding and the opportunity costs of public capital adjust. If we again assume constant output elasticities in the long run, public opportunity costs are given by

$$
\frac{\partial Y}{\partial \mathrm{G}_{\mathrm{i}}}=\left[(1+\lambda)(1+\mathrm{n})-\left(1-\chi_{\mathrm{i}}\right)\right]\left(\frac{\beta}{\beta+\varepsilon_{\mathrm{K}}-\left(\sum_{\mathrm{i}=\mathrm{P}, \mathrm{K}, \mathrm{L}}\left[\left(n+\chi_{\mathrm{i}}\right) \mathrm{G}_{\mathrm{i}}\right] / \mathrm{Y}\right)}\right) .
$$

For public net investment $\sum_{\mathrm{i}=\mathrm{P}, \mathrm{K}, \mathrm{L}}\left[\left(n+\chi_{\mathrm{i}}\right) \mathrm{G}_{\mathrm{i}}\right]$ exceed the income share $\varepsilon_{\mathrm{K}} \mathrm{Y}$ that, according to Eq. (9), equals the optimal source tax revenue, the restriction $\theta_{\mathrm{L}, \mathrm{t}}$ $=0$ raises the opportunity costs of all three public inputs. Therefore the government invests less than it would without this restriction.

\section{Incidence of a source-based capital tax in the long run}

The derived results can be illustrated by examining the functional distribution of income between mobile private capital and labour. For the sake of simplicity only $\mathrm{G}_{\mathrm{K}, \mathrm{t}}$ is considered, whereas the two others types of public capital are neglected. The production function is specified in the form $Y_{t}=L_{t}^{\alpha} K_{t}^{\beta} G_{K, t}^{\varepsilon_{K}}$, where the constant output elasticity with respect to labour, private capital and public capital, $\alpha+\beta$ $+\varepsilon_{\mathrm{K}}=1$ and $\alpha, \beta, \varepsilon_{\mathrm{K}}>0$. In the following, we focus on the steady state and neglect population growth, so that $n=0 .{ }^{11}$

Figure 1 shows the convex partial productivity curve of private capital ( $\partial \mathrm{Y} /$ $\partial \mathrm{K})=\beta(\mathrm{Y} / \mathrm{K})$ for given $\mathrm{G}_{\mathrm{K}}$ and L. Ceteris paribus, an extension of public capital supply $G_{K}$ improves the partial marginal productivity of private capital as a result of the indirect productivity effect and thus shifts the productivity curve upwards. However, this indirect productivity effect does not justify a source tax. We know that

\footnotetext{
$11 \mathrm{Ni}$ and Wang (1995) discuss the stability properties in a comparable system. They show that under the assumptions made the steady states are locally stable.
} 


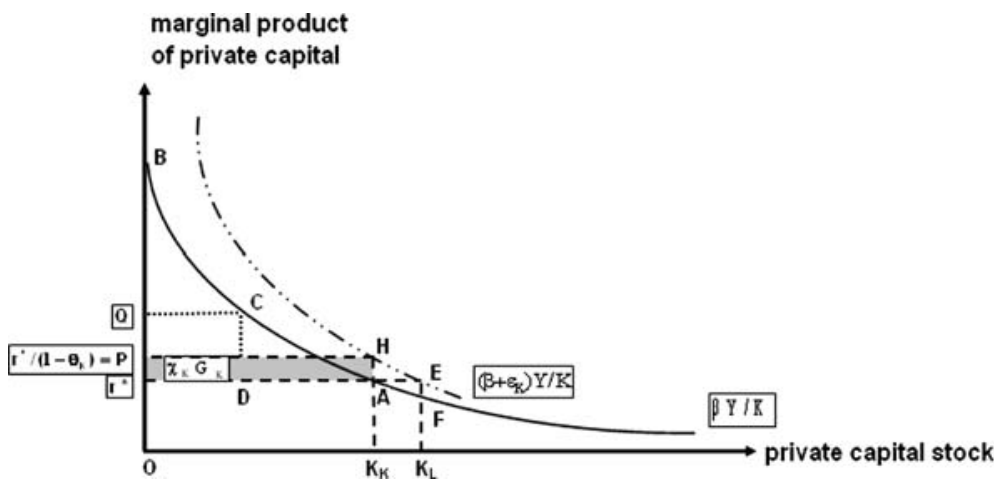

Fig. 1 Incidence of a source tax

the marginal revenue of private capital exceeds its partial marginal product if $\varepsilon_{\mathrm{K}}>0$. Therefore, a second pointed line is drawn in Fig. 1, which shows the marginal revenue of private capital given by $\frac{\partial \mathrm{Y}}{\partial \mathrm{K}}+\frac{\partial \mathrm{Y}_{\mathrm{t}}}{\partial \mathrm{G}_{\mathrm{K}}} \frac{\mathrm{G}_{\mathrm{K}}}{\mathrm{K}}=\left(\beta+\varepsilon_{\mathrm{K}}\right) \frac{\mathrm{Y}}{\mathrm{K}}$. Aggregate income is marked by the marginal productivity curve, but the distribution of the income between the two private factors depends on the pointed auxiliary curve.

When no source tax is levied, $\mathrm{r}^{*}$ is the price of private capital and the market equilibrium is given by $\mathrm{K}_{\mathrm{L}}=\left(\left(\left(\beta+\varepsilon_{\mathrm{K}}\right) / \mathrm{r}^{*}\right) \mathrm{L}^{\alpha} \mathrm{G}_{\mathrm{K}}^{\varepsilon_{\mathrm{K}}}\right)^{1 / 1-\beta}$ since private capital revenue exceeds its partial marginal productivity. The corresponding total output $\mathrm{Y}_{\mathrm{L}}=\left(\left(\left(\beta+\varepsilon_{\mathrm{K}}\right) / \mathrm{r}^{*}\right)^{\beta} \mathrm{L}^{\alpha} \mathrm{G}_{\mathrm{K}}^{\varepsilon_{\mathrm{K}}}\right)^{1 / 1-\beta}$, i.e. gross income of the factors employed in the small open economy, is represented by the area $0 \mathrm{~K}_{\mathrm{L}} \mathrm{FB}$. Total income can be divided into aggregate wage income and aggregate capital income. Since capital income equals $\mathrm{K}_{\mathrm{L}} \mathrm{r}^{*}$, it is shown by the area $0 \mathrm{~K}_{\mathrm{L}}$ Er* and gross wage income $\mathrm{W}_{\mathrm{L}}$ $=\mathrm{Y}_{\mathrm{L}}-\mathrm{K}_{\mathrm{L}} \mathrm{r}^{*}$ is given by the residual ( $\left.\mathrm{r}^{*} \mathrm{AB}-\mathrm{AFE}\right)$. The available income of the private household is given by $\mathrm{V}_{\mathrm{L}}=\mathrm{W}_{\mathrm{L}}-\phi_{\mathrm{L}}$. In the long run, equilibrium public investment and thus the long run costs of providing $\mathrm{G}_{\mathrm{K}}$ are given by $\phi_{\mathrm{L}}=\chi_{\mathrm{K}} \mathrm{G}_{\mathrm{K}}$, as represented in Fig. 1 by the areas $\mathrm{r}^{*} \mathrm{DCQ}$. Using a wage tax as a financing instrument for public infrastructure the available wage income of the private household is represented by the area $\mathrm{V}_{\mathrm{L}}=\left(\mathrm{r}^{*} \mathrm{AB}-\mathrm{AFE}-\mathrm{r}^{*} \mathrm{DCQ}\right)$. If the wage tax is replaced by a source tax, user costs of private capital rise to $\mathrm{r}^{*} /\left(1-\theta_{\mathrm{K}}\right)$ and private capital is driven out of the small open economy. In the equilibrium, the capital stock shrinks from $\mathrm{K}_{\mathrm{L}}$ to $\mathrm{K}_{\mathrm{K}}=\left(\left(\beta / \mathrm{r}^{*}\right) \mathrm{L}_{\mathrm{t}}^{\alpha} \mathrm{G}_{\mathrm{K}, \mathrm{t}}^{\varepsilon_{\mathrm{t}}}\right)^{1 / 1-\beta}$, for $\theta_{\mathrm{K}}=\theta_{\mathrm{K}} *=\varepsilon_{\mathrm{K}} /(1-\alpha)$. The change in the tax instrument further induces a decrease in aggregate income from $\mathrm{Y}_{\mathrm{L}}$ to $\mathrm{Y}_{\mathrm{K}}=\left(\left(\beta / \mathrm{r}^{*}\right)^{\beta} \mathrm{L}_{\mathrm{t}}^{\alpha} \mathrm{G}_{\mathrm{K}, \mathrm{t}}^{\varepsilon_{\mathrm{K}}}\right)^{1 / 1-\beta}$, where $\mathrm{Y}_{\mathrm{K}}$ is represented by the area $0 \mathrm{~K}_{\mathrm{K}} \mathrm{AB}$. The source tax revenue $\phi_{\mathrm{K}}=\chi_{\mathrm{K}} \mathrm{G}_{\mathrm{K}}$ is given by the shaded areas $\mathrm{r}^{*} \mathrm{AHP}$ which 
exactly equals $\mathrm{r}^{*} \mathrm{DCQ}{ }^{12}$ However, the reduction of aggregate output shown by the area $\mathrm{K}_{\mathrm{K}} \mathrm{K}_{\mathrm{L}} \mathrm{FA}$ is not borne by private households. By subtracting the gross capital income $\mathrm{K}_{\mathrm{K}} \mathrm{r}^{*}$, represented by $\mathrm{OK}_{\mathrm{K}} \mathrm{Ar}^{*}$ and the source tax revenue $\mathrm{r}^{*} \mathrm{AHP}$ from the aggregate income $\mathrm{Y}_{\mathrm{K}}$, one derives the available wage income of the private households $\mathrm{W}_{\mathrm{K}}=\mathrm{V}_{\mathrm{K}}=\left(0 \mathrm{~K}_{\mathrm{K}} \mathrm{AB}-0 \mathrm{~K}_{\mathrm{K}} \mathrm{Ar} *-\mathrm{r}^{*} \mathrm{AHP}\right) .{ }^{13}$ Compared to the case where a wage tax is levied, the available income $V_{K}$ exceeds $V_{L}$ by AFE.

\section{Conclusions}

The idea that even in conditions of fiscal competition mobile capital can be taxed according to the benefit principle to finance public infrastructure is widespread. Oates (1999) argues that if capital tax revenue is used by government to supply public infrastructure that improves the productivity of private capital, the tax-induced increase of the costs of capital in the jurisdiction will be compensated by an increase in the return of capital and thus counteract the capital outflow. However, the question remains whether the benefit of a capital inflow induced by infrastructure that is financed by a tax on immobile factors exceeds the benefit of a source tax.

Taking the perspective of a small, open and autonomous jurisdiction, it can be shown that the optimal financing instrument of public infrastructure depends on some technical properties of the publicly provided inputs. Public inputs of the "creation of atmosphere" type should not be financed by a source tax on mobile capital despite the fact that these inputs have an indirect productivity-enhancing effect on private capital. The same holds for publicly provided private inputs that are bound on labour. Public inputs, that evoke only indirect productivity effect on private capital, does not justify a source tax on the mobile factor. Actually, a source tax is an efficient financing instrument only for public capital that generates a factor rent on private capital. If such a factor rent occurs, it should be confiscated by the government through a source tax. If the government is, for whatever reason, restricted to a wage or a source tax, the supply of public capital can become suboptimal.

\section{Appendix}

This appendix presents some results derived in the text:

$$
\begin{aligned}
\mathrm{Z}\left(\phi_{\mathrm{K}, \mathrm{t}}, \phi_{\mathrm{L}, \mathrm{t}}, \mathrm{G}_{\mathrm{i}, \mathrm{t}+1}, \mathrm{~K}_{\mathrm{t}+1}\right)=\Psi+ & \sum_{\mathrm{t}=1}^{T} \mu_{\mathrm{t}}\left[\phi_{\mathrm{L}, \mathrm{t}}+\phi_{\mathrm{K}, \mathrm{t}}-\sum_{\mathrm{i}=\mathrm{P}, \mathrm{K}, \mathrm{L}} \mathrm{G}_{\mathrm{i}, \mathrm{t}+1}+\left(1-\chi_{\mathrm{i}}\right) \mathrm{G}_{\mathrm{i}, \mathrm{t}}\right] \\
& +\sum_{\mathrm{t}=1}^{T} \rho_{\mathrm{t}}\left[\mathrm{Y}_{\mathrm{t}}\left(\mathrm{G}_{\mathrm{i}, \mathrm{t}}, \mathrm{K}_{\mathrm{t}}\right)-\mathrm{W}_{\mathrm{t}}\left(\mathrm{G}_{\mathrm{i}, \mathrm{t}}, \mathrm{K}_{\mathrm{t}}\right)-\phi_{\mathrm{K}, \mathrm{t}}-\mathrm{r}^{*} \mathrm{~K}_{\mathrm{t}}\right]
\end{aligned}
$$

\footnotetext{
${ }^{12}$ Note, that the source tax revenue $\chi_{\mathrm{K}} \mathrm{G}_{\mathrm{K}}=\phi_{\mathrm{K}}$ meets Eq. 9 only if $\lambda=0$.

${ }^{13} V_{\mathrm{L}}=V_{\mathrm{K}}\left[\left(\left(\beta+\varepsilon_{\mathrm{K}}\right) / \beta\right)^{\frac{\beta}{1-\beta}}-\left(\varepsilon_{\mathrm{K}} / \alpha\right)\right]$ and $\left[\left(\left(\beta+\varepsilon_{\mathrm{K}}\right) / \beta\right)^{\frac{\beta}{1-\beta}}-\left(\varepsilon_{\mathrm{K}} / \alpha\right)\right]<1$
} 


$$
\begin{gathered}
\frac{\partial \mathrm{Z}}{\partial \phi_{\mathrm{L}, \mathrm{t}}}=\frac{\partial \Psi}{\partial \phi_{\mathrm{L}, \mathrm{t}}}+\mu_{\mathrm{t}} \leq 0 ; \\
\frac{\partial \mathrm{Z}}{\partial \phi_{\mathrm{K}, \mathrm{t}}}=\mu_{\mathrm{t}}-\rho_{\mathrm{t}} \leq 0, \quad \phi_{\mathrm{L}, \mathrm{t}} \geq 0 ; \phi_{\mathrm{L}, \mathrm{t}} \frac{\partial Z}{\partial \phi_{\mathrm{L}, \mathrm{t}}}=0 \\
\frac{\partial \mathrm{Z}}{\partial \mathrm{K}_{\mathrm{t}+1}}=\frac{\partial \Psi}{\partial \mathrm{K}_{\mathrm{t}+1}}+\rho_{\mathrm{t}+1}\left[\frac{\partial\left(\mathrm{Y}_{\mathrm{t}+1}-\mathrm{W}_{\mathrm{t}+1}\right)}{\partial \mathrm{K}_{\mathrm{t}+1}}-\mathrm{r}_{\mathrm{K}, \mathrm{t}} \frac{\partial \mathrm{Z}}{\partial \phi_{\mathrm{K}, \mathrm{t}}}=0\right. \\
\rho_{\mathrm{t}+1}=-\frac{\left.\partial \frac{\partial \Psi}{\partial \mathrm{K}_{\mathrm{t}+1}}\right]}{\left[\frac{\partial\left(\mathrm{Y}_{\mathrm{t}+1}-\mathrm{W}_{\mathrm{t}+1}\right)}{\partial \mathrm{K}_{\mathrm{t}+1}}-\mathrm{r}^{*}\right]} \\
\frac{\partial \mathrm{Z}}{\partial \mathrm{G}_{\mathrm{i}, \mathrm{t}+1}}=\frac{\partial \Psi}{\partial \mathrm{G}_{\mathrm{i}, \mathrm{t}+1}}-\mu_{\mathrm{t}}+\mu_{\mathrm{t}+1}\left(1-\chi_{\mathrm{i}}\right)+\rho_{\mathrm{t}+1}\left[\frac{\partial\left(\mathrm{Y}_{\mathrm{t}+1}-\mathrm{W}_{\mathrm{t}+1}\right)}{\partial \mathrm{G}_{\mathrm{i}, \mathrm{t}+1}}\right]=0
\end{gathered}
$$

Eliminating the Lagrange parameters and replacing $\phi_{\mathrm{K}, \mathrm{t}}^{*}=\theta_{\mathrm{K}, \mathrm{t}}^{*}\left(\mathrm{Y}_{\mathrm{t}}-\mathrm{W}_{\mathrm{t}}\right)=\left[\partial \mathrm{Y}_{\mathrm{t}} / \partial \mathrm{G}_{\mathrm{K}, \mathrm{t}}\right] \mathrm{G}_{\mathrm{K}, \mathrm{t}}$ according to (9) we receive the modified golden rule of public investment presented in (10).

\section{References}

Arrow KJ, Kurz W (1970) Public investment, the rate of return and optimal fiscal policy. Baltimore Barro RJ, Sala-i-Martin X (1995) Economic growth. McGraw-Hill

Büttner T, Schwager R, Stegarescu D (2004) Agglomeration, population size, and the cost of providing public services: an empirical analysis for German states. ZEW Discussion Paper No. 04-18

European Commission (2005) Working together for growth and jobs: a new start for the Lisbon strategy. Communication from President Barroso in agreement with Vice-President Verheugen COM (2005) 24, Brussels

Feehan JP (1989) Pareto-efficiency with three varieties of public input. Public Finance 44:237-248

Feehan JP, Matsumoto M (2000) Productivity-enhancing public investment and benefit taxation: the case of factor-augmenting public inputs. Can J Eco 33:114-121

Gerber RI, Hewitt DP (1987) Decentralized tax competition for business capital and national economic efficiency. J Reg Sci 27:451-460

Gramlich EM (1994) Infrastructure investment: a review essay. J Eco Lit 32:1176-1196

Huizinga H, Nielsen SB (1997) Capital income and profit taxation with foreign ownership of firms. J Int Eco 42:149-165

Kaizuka K (1965) Public goods and decentralization of production. Rev Eco Stat 47:118-120

Kellermann K (2006) A note on intertemporal fiscal competition and redistribution. Int Tax Public Finance 13:151-161

Marchand M, Pestieau P (1984) Discount rates and shadow prices for public investment. J Public Econ 24:153-169

Marglin SA (1963) The opportunity costs of public investment. Quarterly J Eco 77:274-289

Matsumoto M (2000) A tax competition analysis of congestible public inputs. J Urban Eco 48:242-259

Matsumoto M (1998) A note on tax competition and public input provision. Reg Sci Urban Eco 28:465-473

McMillan J (1979) A note on the economics of public intermediate goods. Public Finance 34:293-299

Meade JE (1952) External economies and diseconomies in a competitive situation. Eco J 62:54-67 
Ni S, Wang X (1995) Balanced government budgets versus deficit finance in a growth economy. Can J Eco 28:1120-1134

Noiset L (1995) Pigou, Tiebout, property taxation, and the underprovision of local public goods: comment. J Urban Eco 38:312-316

Oates WE (1999) An essay on fiscal federalism. J Econ Lit 37:1120-1149

Oates WE, Schwab RM (1991) The allocative and distributive implications of local fiscal competition. In: Kenyon DA, Kincaid J (eds) Competition among state and local governments, Washington DC, pp $127-145$

Oates WE, Schwab RM (1988) Economic competition among jurisdictions: efficiency enhancing or distortion inducing? J Public Econ 35:333-354

OECD (2005) Education at a glance: OECD indicators 2005. Paris

Pfähler W, Hofmann U, Bönte W (1997) Does extra public infrastructure capital matter? An appraisal of empirical literature. Finanzarchiv N. F. 53:68-112

Reiter M, Weichenrieder A (1997) Are public goods public? A critical survey of the demand estimates for local public services. Finanzarchiv N. F. 54:374-408

Richter WF (1994) The efficient allocation of local public factors in Tiebout's tradition. Reg Sci Urban Econ 24:323-340

Sandmo A (1972) Optimality rules for the provision of collective factors of production. J Public Econ 1:149-157

Sandmo A, Drezé JH (1971) Discount rates for public investment in closed and open economies. Economica XXXVIII:395-412

Sinn HW (1997) The selection principle and market failure in systems competition. J Public Econ 66:247-274

Sinn HW (2003) The new systems competition. Blackwell, Oxford

Wildasin DE (2003a) Fiscal competition: an introduction. J Public Econ Theory 5:169-176

Wildasin DE (2003b) Fiscal competition in space and time. J Public Econ 87:2571-2588

Wildasin DE (2000) Factor mobility and fiscal policy in the EU: policy issues and analytical approaches. Economic policy: a European forum. October 2000, pp 337-368

Wilson JD, Gordon R (2003) Expenditure competition. J Public Econ Theory 5:399-417

Zodrow GR, Mieszkowski P (1986) Pigou, Tiebout, property taxation, and the under-provision of local public goods. J Urban Econ 19:356-370

Zodrow GR (2006) Capital mobility and source-based-taxation of capital income in small open economies. Int Tax Public Finance 13:269-294 